\title{
Effect of glutinous rice flour and dried egg white in fabrication of porous cordierite by gel casting method
}

\section{(Efeito da farinha de arroz glutinoso e clara de ovo seco na fabricação de cordierita porosa pelo método gel casting)}

\author{
A. Kamil Fakhruddin ${ }^{1}$, Hasmaliza Mohamad ${ }^{\text {* }}$ \\ ${ }^{1}$ Universiti Sains Malaysia, School of Materials and Mineral Resources, Structural Materials Niche Area, \\ Engineering Campus, 14300 Nibong Tebal, Penang, Malaysia
}

\begin{abstract}
In this study, cordierite was produced using $\mathrm{MgO}, \mathrm{SiO}_{2}$ and $\mathrm{Al}_{2} \mathrm{O}_{3}$ as raw materials through glass route method. The raw materials were mixed for $6 \mathrm{~h}$ and the mixture was melted at $1550{ }^{\circ} \mathrm{C}$ and then water quenched. The glass produced was milled for $5 \mathrm{~h}$ to obtain fine powder, which was used to prepare porous cordierite through gel casting method. The effect of addition of different natural binders, glutinous rice flour (GRF) and dried egg white (DEW), on porous cordierite was investigated. GRF and DEW were added to the slurry during mixing. The synthesized cordierite powder was analyzed by X-ray diffraction. Porous cordierite was characterized through Archimedes method, morphological analysis, and compression test. The porosity level varied from $60.6 \%$ to $78.7 \%$ depending on the amount of natural binder added. Compression test results showed that the compressive strength of porous cordierite increased with increasing amount of natural binder added.
\end{abstract}

Keywords: porous cordierite, natural binder, gel casting.

\section{Resumo}

Neste estudo, cordierita foi produzida utilizando $\mathrm{MgO}$, $\mathrm{SiO}_{2}$ e $\mathrm{Al}_{2} \mathrm{O}_{3}$ como matérias-primas pelo método do vidro. As matériasprimas foram misturadas por $6 \mathrm{~h}$ e a mistura foi fundida a $1550{ }^{\circ} \mathrm{C} e$, em seguida, resfriada rapidamente em água. $O$ vidro produzido foi moído por $5 \mathrm{~h}$ para obter pó fino, que foi usado para preparar cordierita porosa pelo método gel casting. Foram investigados o efeito da adição de diferentes ligantes naturais, farinha de arroz glutinoso (GRF) e clara de ovo seco (DEW), na cordierita porosa. GRF e DEW foram adicionados à suspensão durante a mistura. O pó de cordierita sintetizado foi analisado por difração de raios X. A cordierita porosa foi caracterizada pelo método de Arquimedes, análise morfológica e teste de compressão. O nível de porosidade variou de 60,6\% a 78,7\%, dependendo da quantidade de ligante natural adicionado. Os resultados do teste de compressão mostraram que a resistência à compressão da cordierita porosa aumentou com a quantidade crescente de ligante natural adicionado.

Palavras-chave: cordierita porosa, ligante natural, gel casting.

\section{INTRODUCTION}

Cordierite is a useful crystalline phase in the $\mathrm{MgO}$ $\mathrm{Al}_{2} \mathrm{O}_{3}-\mathrm{SiO}_{2}$ ternary system [1]. It has gained considerable interest for a wide range of application because of its excellent properties, such as low thermal coefficient, good thermal shock resistance, and ability to retain high mechanical strength at high temperatures [2]. Cordierite is also fabricated into a porous structure due to demand in various application. Porous cordierite possesses a unique structure characterized by low density and low thermal conductivity and high porosity, low thermal coefficient and high permeability [3]. Porous cordierite is applied in automotive industry, electronic industry, high temperature air filter, and kiln furniture [2].

The performance of porous ceramics is strongly

*hasmaliza@.usm.my,ccj7060@gmail.com influenced by pore size, pore distribution, interconnection of pore and stiffness of the wall or strut. These requirements are strictly dependent on the production processing route [4]. Porous ceramics can be fabricated by few techniques, such as sponge replication [5], sol-gel routes [1], starch consolidation [6], and gel casting [7]. Fukushima et al. [8] used freeze casting to fabricate porous cordierite with low compressive strength. Jamaluddin et al. [9] discovered that reticulated porous ceramics with cracks exhibited low strength when produced through sponge replication. Therefore, in order to solve the strength issues in fabrication of porous cordierite gel casting method was proposed. This method produces porous ceramics with excellent properties, such as high mechanical strength, minimal defect, and complex shapes [10]. In gel casting, slurry with rigid polymeric network that bond the ceramic particles is casted [11].

Generally, cordierite slurry is added with binders to improve the strength of porous cordierite. Binders are 
classified as natural polymeric and synthetic polymeric binders; these materials typically consist of long chains of polymer networks that provide strength via the bond between particles [4]. The networks also provide plasticity and contribute to the formation of green body [12]. Compared with synthetic binders, natural binders offer several advantages, such as nontoxicity and low cost of materials [13]. Natural binders include starches, agar, protein, and natural fibers, which are commonly utilized in the production of porous structure. Starch is the most commonly used because it easily gelatinizes due to its low gelatinization temperature, high viscosity, low-gel syneresis, and flexibility [4]. Glutinous rice flour (GRF) is a natural and nontoxic starch that contains high amounts of polysaccharide. This polysaccharide causes particles to stick together as a result of gradual decrease in the amount of water available for flowing. Consequently, the system consolidates into a solid body. GRF consists of two gels, which gelatinizes in aqueous solution at a certain temperature; upon incorporation of a necessary amount of GRF, the slurry gelatinizes in the aqueous phase when heated up and transform into a rigid body. Thus, green bodies solidified with GRF are predicted to exhibit improved mechanical properties [14]. In comparison to starch, egg white is used as binder. Alleoni [15] reported that egg white contains albumin and is an abundant protein source. Egg white, also known as albumen, mainly contains ovalbumin [16]. Egg white also contains glucose and exhibits enhanced gel properties, such as gel strength [17]. The use of ovalbumin in shape forming of ceramics is made possible through gel casting. This paper proposes the use of gel casting of cordierite powder incorporated with GRF and DEW (dried egg white) binders in order to improve the strength of porous ceramics. The effect of GRF and DEW on the fabrication of porous cordierite through gel casting is widely explored.

\section{EXPERIMENTAL}

Synthesis of cordierite powder: alumina $\left(\mathrm{Al}_{2} \mathrm{O}_{3}\right)$, magnesia $(\mathrm{MgO})$, and silica $\left(\mathrm{SiO}_{2}\right)$ (Ipoh Ceramic Sdn. Bhd.) powders were used to produce cordierite powder through glass melting method at $1550{ }^{\circ} \mathrm{C}$. Molten glass was water quenched, crushed, and milled for $5 \mathrm{~h}$ at $400 \mathrm{rpm}$. The powder produced was sintered at $980^{\circ} \mathrm{C}$ for $2 \mathrm{~h}$.

Fabrication of cordierite powder with $3 D$ structure: cordierite powder $(67.1 \mathrm{~g})$, distilled water $(28.8 \mathrm{~g})$, and polyethyeneimine ( $4.1 \mathrm{~g}$ ) (Sigma-Aldrich) as dispersant were mixed with various amounts of GRF - glutinous rice flour (2.5, 4.0 and $6.0 \mathrm{~g}$ ) (Erawan Brand) and DEW - dried egg white $(1.5,2.5$ and $4.0 \mathrm{~g})$ at $600 \mathrm{rpm}$ for $2 \mathrm{~h}$. The hen egg white was separated with egg yolk and was artificially dried at $60^{\circ} \mathrm{C}$ for $5 \mathrm{~h}$. Then, it was milled using planetary high mill for $1 \mathrm{~h}$ at $400 \mathrm{rpm}$. The milled DEW powder was sieved. The mixture was added with sodium dodecyl sulphate (Sigma-Aldrich) as foaming agent, and the cordierite slurry was vigorously whisked at $1000 \mathrm{rpm}$ for foaming process. The slurry was then whisked at $600 \mathrm{rpm}$ and added with $1.4 \mathrm{wt} \%$ gelation agent, Denacol-EX-614B (Nagase Chemical, Japan) immediately after foaming. The bubbled cordierite slurry was molded and sealed for $1 \mathrm{~h}$ at room temperature. The rectangular shape with $20 \times 80 \mathrm{~mm}$ Teflon mold was used to pour the slurry. The wet green bodies were demoulded and immediately placed into a drying oven at $80{ }^{\circ} \mathrm{C}$ for 24 h. The dried bodies were sintered at $1350{ }^{\circ} \mathrm{C}$ for $2 \mathrm{~h}$ by using two different stages: $100^{\circ} \mathrm{C} / \mathrm{h}$ heating rate from room temperature up to $600{ }^{\circ} \mathrm{C}$, followed by $200{ }^{\circ} \mathrm{C} / \mathrm{h}$ heating rate up to $1350{ }^{\circ} \mathrm{C}$. The samples were slowly cooled to room temperature.

Characterization: the properties of the synthesized cordierite powder were characterized using X-ray diffraction (XRD) analysis. The density and porosity of porous cordierite were characterized using Archimedes method. The mechanical properties of porous cordierite were determined by conducting compression test with a universal testing machine (Instron) at a crosshead of $1 \mathrm{~mm} / \mathrm{min}$. Morphological study was performed using tabletop scanning electron microscope (SEM).

\section{RESULTS AND DISCUSSION}

\section{Characterization of cordierite powder}

Fig. 1 shows the glass produced after quenching at a melting temperature of $1550{ }^{\circ} \mathrm{C}$. The glass was placed on the white paper under the fluorescent light to observe the physical appearance. The glass produced appeared transparent due to the insignificant amount of coloring minerals in the glass composition and the rapid cooling of the molten state, which was sufficiently fast to avoid crystallization. This phenomenon is due to the random stacking of the molecules in the glass, leading to the formation of such gap, which is filled with air and used as scattering point for light penetration [18]. After the glass was milled for $5 \mathrm{~h}$, the powder particle size was analysed. Fig. 2 shows the distribution of particle size of glass powder after milling. Based on the result obtained from particle analyser, Malvern, the average particle size of glass powder, $\mathrm{d}_{50}$, was $7.39 \mu \mathrm{m}$.

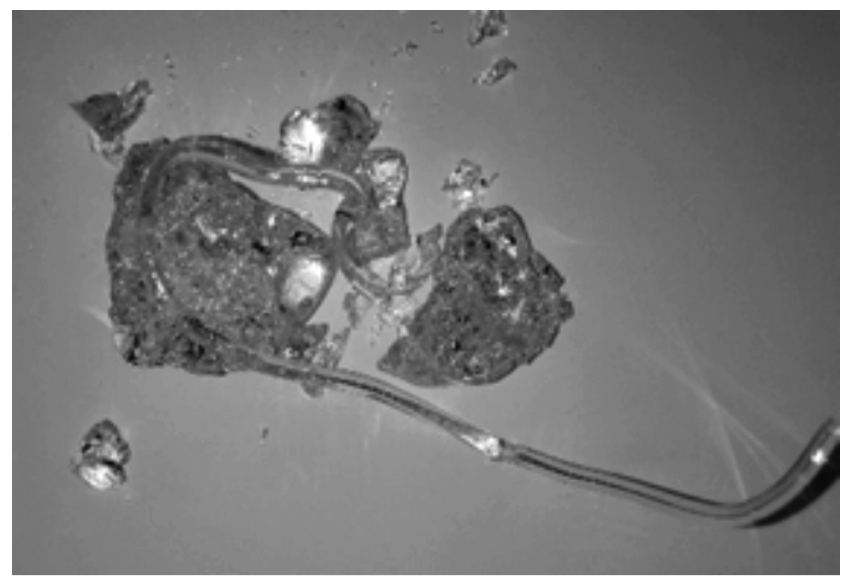

Figure 1: Glass produced after quenching.

[Figura 1: Vidro produzido por resfriamento brusco.] 


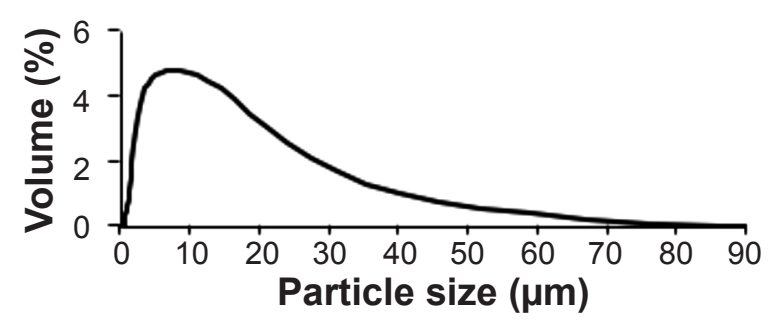

Figure 2: Particle size distribution curve of milled cordierite powder.

[Figura 2: Curva de distribuição granulométrica do pó de cordierita moído.]

XRD analysis was conducted to confirm that the glass was produced after quenching. Fig. 3a shows the XRD pattern of the glass powder. A large amorphous hump and no crystalline peaks were detected in the diffraction pattern of the sample melted at $1550{ }^{\circ} \mathrm{C}$. The absence of peaks in the XRD pattern indicated that the compound was completely transformed into amorphous or glassy phase. Atoms in the glass were randomly moved during melting [19], producing an amorphous hump in the XRD pattern. The amorphous phase of the glass was proven by the transparent appearance shown in Fig. 1. Fig. 3b shows the XRD pattern of sample sintered at $980{ }^{\circ} \mathrm{C}$ for $2 \mathrm{~h}$. Cordierite was found to be the major crystalline phase formed after sintering. The selected temperature is similar to that reported in [20]; in this study,
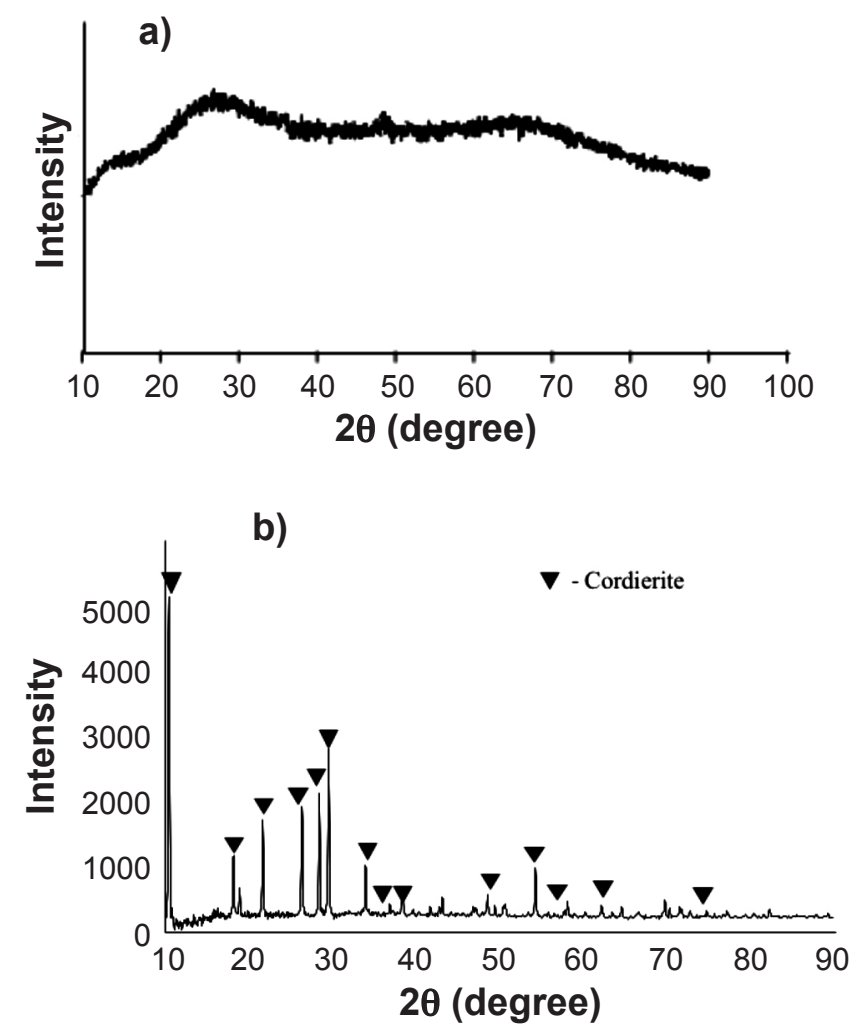

Figure 3: X-ray diffraction patterns of: (a) glass powder produced after quenching; and (b) sintered condierite.

[Figura 3: Difratogramas de raios X de: (a) pó de vidro produzido por resfriamento brusco; $e$ (b) cordierita sinterizada.] cordierite powder samples were produced using the same composition of raw materials.

\section{Characterization of porous cordierite}

Effect of GRF (glutinous rice flour): Fig. 4 shows the SEM results corresponding to the cross-section of porous cordierite fabricated with different binder contents. Fig. 4a shows that porous cordierite possessed uniformly distributed pore, interconnected structure and pore size of 54-122 $\mu \mathrm{m}$. The homogeneity of pore distribution is attributed to the stability of foam in the green stage, whereas the near net shape structure is due to the nature of the foaming process in gel casting. Similarly, Tulliani and Lombardi [21] produced porous ceramics through gel casting. Figs. $4 \mathrm{~b}, 4 \mathrm{c}$ and $4 \mathrm{~d}$ show that porous cordierite produced with GRF contained more pores compared with the sample without GRF. In addition, samples with GRF exhibited uniform pore distribution and interconnected structure regardless of the amount of GRF added. The pore size increased with increasing amount of GRF added, and cracks were observed on some struts. The GRF acted as pore former because it is burnt out and leaves a cavity in the porous structure [4].

Fig. 5 shows the correlation of porosity and compressive strength with the amount of GRF binder used in porous cordierite. The porosity of porous cordierite increased with increasing amount of binder added. The porosity of porous cordierite without any binder was $60.6 \%$, which increased up to $78.7 \%$ when added with $6.0 \mathrm{~g}$ of GRF. This phenomenon was attributed to the burn out of GRF, leaving a cavity after sintering. Jamaluddin et al. [4] reported that starch functions as pore forming agent in porous ceramics, thereby creating pores after burn out and forming loosely packed cordierite particles. Consistently, Wan et al. [11] stated that the burn out of starch leaves cavities, which eventually form pores. Thus, the number of cavity increased with increasing amount of starch. Fig. 3 shows that the pore size of porous cordierite added with GRF increased, leading to enhanced porosity. The compressive strength of porous cordierite increased from 5.43 to $9.13 \mathrm{MPa}$ upon addition of 0 to $4 \mathrm{~g}$ of GRF (Fig. 5). The compressive strength decreased to $8.45 \mathrm{MPa}$ when $6 \mathrm{~g}$ of GRF was added. The increase in strength with the addition of GRF could be due to the long chain of polysaccharides comprising glucose monomer linkages possessing gelling properties. The long chain of polymer networks in GRF primarily provides strength by building bridges among the particles [12]. When the amount of GRF added was increased up to $6.0 \mathrm{~g}$, the strength of porous cordierite decreased because of extremely high porosity (78.7\%). Wan et al. [14] indicated that GRF also acts as pore-forming agent in porous ceramics. With increasing amount of GRF, the porosity of porous cordierite increases and the strength of porous ceramics decreases. Nevertheless, in the present case, the strength increased as the porosity increased when $4 \mathrm{~g}$ of GRF was added. This finding could be attributed to the bonding bridges among particles developed by the strong long chain of polymer network that can support the increase in porosity [12]. When the amount 

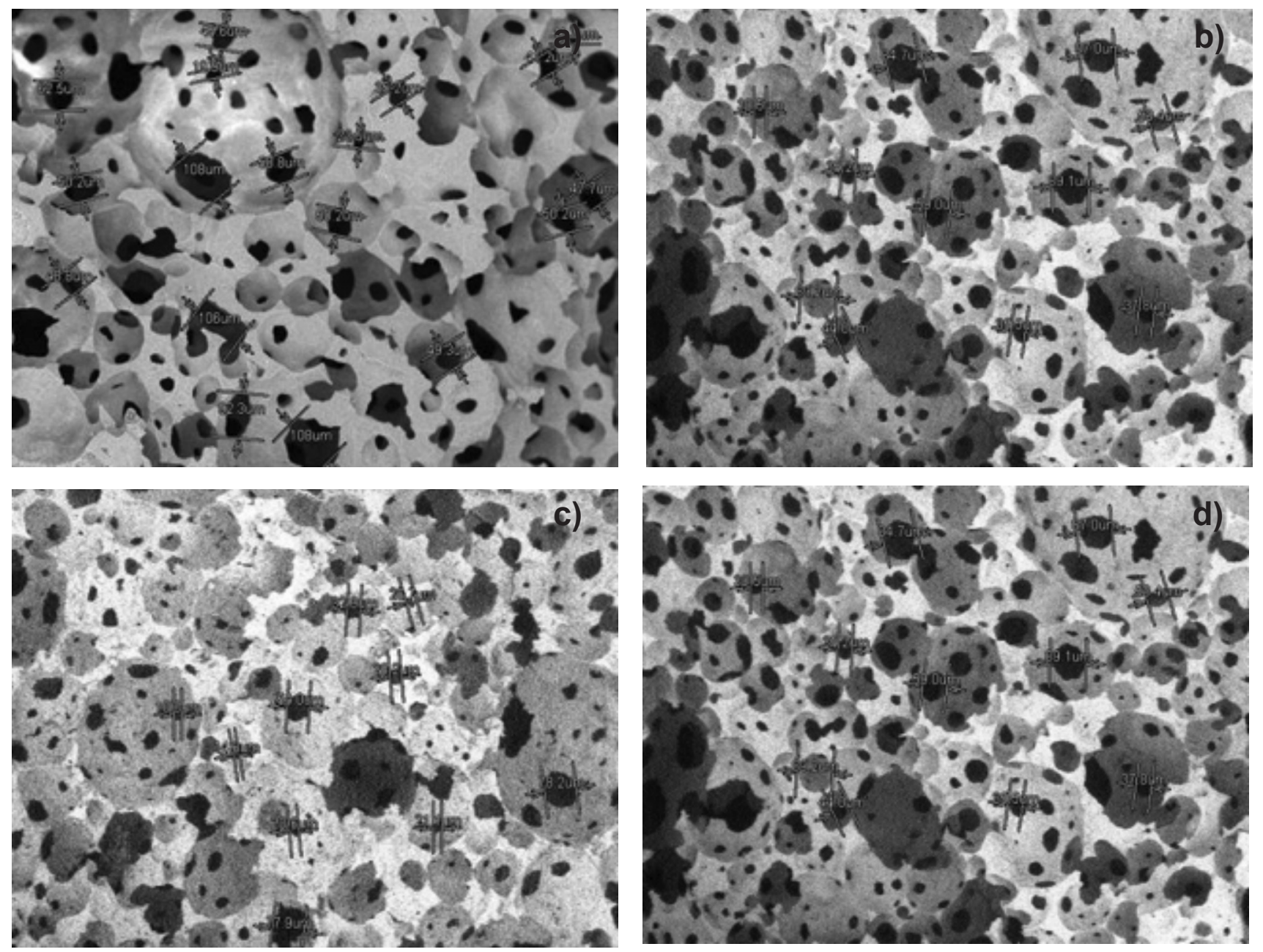

Figure 4: SEM micrographs of cross section of porous cordierite with different binder content: (a) without binder; (b) $2.5 \mathrm{~g}$ of GRF; (c) 4.0 $\mathrm{g}$ of GRF; and (d) $6.0 \mathrm{~g}$ of GRF.

[Figura 4: Micrografias obtidas por microscopia eletrônica de varredura da seção de cordierita porosa com diferentes teores de ligante: (a) sem ligante; (b) 2,5 g de GRF; (c) 4,0 g de GRF; e (d) 6,0 g de GRF.]

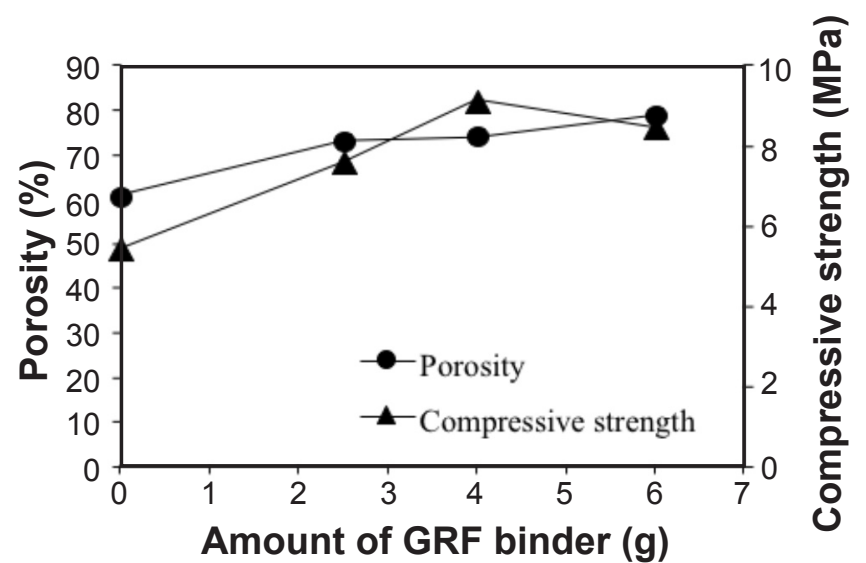

Figure 5: Correlation of porosity and compressive strength with different amount of GRF of porous cordierite.

[Figura 5: Correlação de porosidade e resistência à compressão com diferentes teores de GRF da cordierita porosa.]

of GRF added reached $6 \mathrm{~g}$, the strength of porous cordierite decreased because the long-chain polymer network cannot support the extreme porosity effect.
Effect of DEW (dried egg white): Fig. 6 shows the effect of DEW on the microstructure of porous cordierite. Figs. $6 \mathrm{~b}, 6 \mathrm{c}$ and $6 \mathrm{~d}$ show the uneven distribution of pores in all samples. The mean pore sizes were 43-190, 52-155 and 77$177 \mu \mathrm{m}$ for samples added with $1.5,2.5$ and $4 \mathrm{~g}$ of DEW, respectively. The pore size increased with increasing amount of DEW. DEW was added as binder and pore former, leading to burn out during sintering and leaving cavity in the porous structure [14]. In addition, cracks were formed on some struts upon addition of DEW. The cracks became worse when the amount of DEW added was increased up to $4 \mathrm{~g}$. The presence of cracks contributed to the rough surface of the wall; by contrast, the sample without DEW exhibited a smooth surface. This phenomenon could be attributed to the gelling behavior of DEW, which tends to agglomerate in the slurry, producing the rough surface of the formed porous cordierite [16]. However, the microstructure of samples added with $6 \mathrm{~g}$ of DEW was not observed because the structure collapsed.

Fig. 7 shows the correlation of porosity and compressive strength with the amount of DEW added to porous cordierite. 

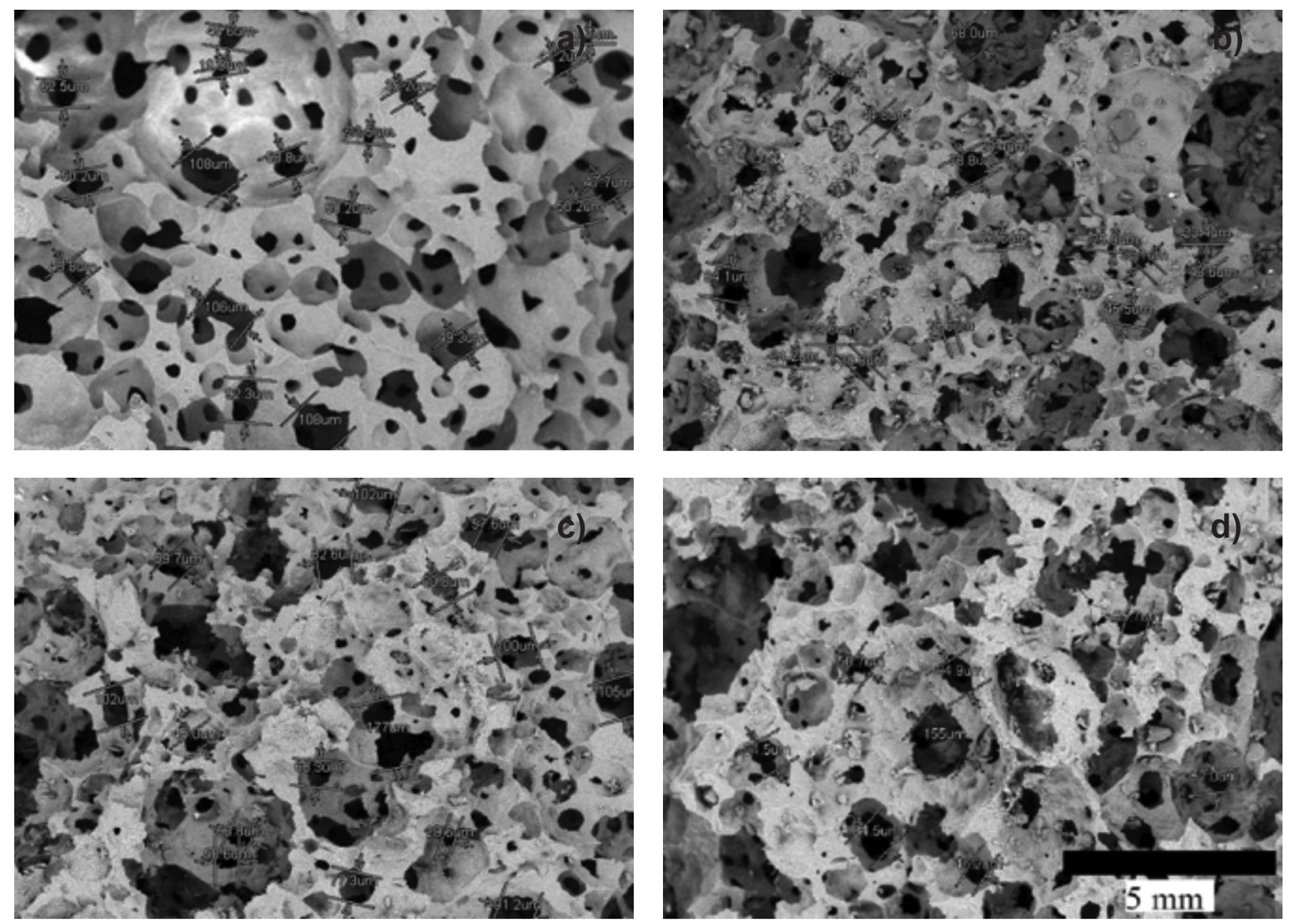

Figure 6: SEM micrographs of cross section of porous cordierite with different binder content: (a) without binder; (b) $1.5 \mathrm{~g}$ of DEW; (c) 2.5 $\mathrm{g}$ of DEW; and (d) $4.0 \mathrm{~g}$ of DEW.

[Figura 6: Micrografias obtidas por microscopia eletrônica de varredura da seção de cordierita porosa com diferentes teores de ligante: (a) sem ligante; (b) 1,5 g de DEW; (c) 2,5 g de DEW; e (d) 4,0 g de DEW.]

The porosity increased from $60.6 \%$ to $68.3 \%$ when $4 \mathrm{~g}$ of DEW was added. The porosity increased with increasing amount of DEW added because it acted as binder and pore-forming agent, which was burnt out during sintering. The binder may enable particle-to-particle contact and may form loosely packed cordierite particles, resulting in increased porosity. With increasing amount of DEW added, the packing of cordierite particles became looser, thereby increasing the porosity [22]. Fig. 6 also shows that the porous cordierite added with DEW possessed large pore size and consisted of hollow structure; these properties contributed to the increase in porosity. The compressive strength of porous cordierite increased from 5.43 to $5.72 \mathrm{MPa}$ when $2.5 \mathrm{~g}$ of DEW was added (Fig. 7). However, the compressive strength significantly decreased to 4.20 MPa upon the addition of $4 \mathrm{~g}$ of DEW. The increase in compressive strength could be due to the albumen content of DEW; albumen contains long chains and contributes to strength improvement. This finding is in agreement with previous research on DEW used as binder. The study indicated that DEW, also known as albumen, mainly contains ovalbumin consisting of long chain

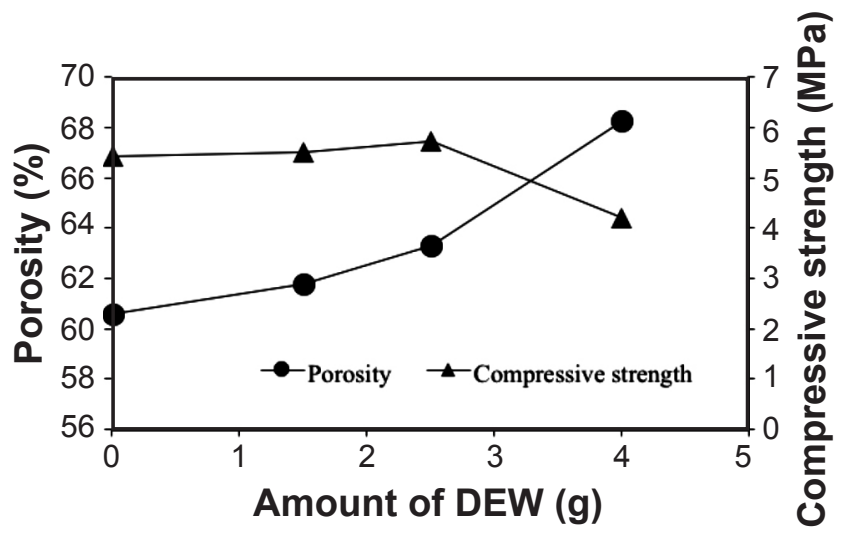

Figure 7: Correlation of porosity and compressive strength with different amount of DEW of porous cordierite.

[Figura 7: Correlação de porosidade e resistência à compressão com diferentes teores de DEW da cordierita porosa.]

monomers and cross-linkers. The long-chain polymer networks in DEW provide strength by building bridges among the particles of cordierite [12]. The compressive strength of porous cordierite significantly decreased when $4.0 \mathrm{~g}$ of DEW was added because of excess porosity 
(68.3\%) produced. As the fact, the strength is inversely proportional with porosity, but in this case the strength increased despite the porosity increase. This is due the strength provide by long chain of DEW. When the 4.0 $\mathrm{g}$ of DEW was added, the porous cordierite had excess porosity which provided loss of strength over the strength by long chain of DEW. Alleoni [15] reported that DEW also acted as pore-forming agent in porous ceramics; with increasing amount of DEW, the porosity increases and the strength of the porous ceramics increase. In addition, DEW acted as a pore-forming agent, which was burnt out during sintering. DEW enabled particle-to-particle contact and formed loosely packed cordierite particles, leading to increased porosity. Moreover, the increasing amount of DEW contributed to the loose arrangement of the cordierite particles, resulting in enhanced porosity [23]. The presence of cracks, observed in the SEM image, led to decrease in the compressive strength.

\section{CONCLUSIONS}

Cordierite powder was successfully synthesized from oxide-based raw materials $\left(\mathrm{SiO}_{2}, \mathrm{MgO}\right.$ and $\left.\mathrm{Al}_{2} \mathrm{O}_{3}\right)$ through glass route method. Porous cordierite was also successfully fabricated using different natural binders (GRF - glutinous rice flour, and DEW - dried egg white) through gel casting. The addition of different amounts of GRF (2.5, 4.0 and $6.0 \mathrm{~g})$ and DEW $(1.5,2.5$ and $4.0 \mathrm{~g})$ were found to affect the properties of porous cordierite. The porosity of porous cordierite ranged from $60.6 \%$ (without binders) to $78.7 \%$ (6 $\mathrm{g}$ of GRF). The porosity increased with increasing amount of binders. Furthermore, the compression strength of porous cordierite ranged from $5.43 \mathrm{MPa}$ (without binder) to $9.13 \mathrm{MPa}$ ( $4 \mathrm{~g}$ of GRF). The compressive strength increased upon addition of $4 \mathrm{~g}$ of GRF and $2.5 \mathrm{~g}$ of DEW but decreased upon addition of $6 \mathrm{~g}$ of GRF and $4 \mathrm{~g}$ of DEW. The pore structure of the sample added with GRF retained its structural integrity, whereas that of the sample added with DEW possessed large pore size and collapsed structure with numerous cracks. Hence, GRF exhibited better performance as binder in porous cordierite than DEW.

\section{ACKNOWLEDGEMENT}

The authors are grateful to the Ministry of Education, Malaysia for financial support under FRGS (6071300).

The authors are grateful to the Ministry of Education, Malaysia for financial support under FRGS (6071300).

\section{REFERENCES}

[1] X. Guo, K. Nakanishi, K. Kanamori, Y. Zhu, H. Yang, J. Eur. Ceram. Soc. 34 (2014) 817.

[2] H. Schneider, J. Schreur, B. Hildmann, J. Eur. Ceram. Soc. 28 (2008) 329.

[3] P. Colombo, J.R. Hellman, Mater. Res. Innov. 6 (2002) 260.

[4] A.R. Jamaludin, S.R. Kasim, M.Z. Abdullah, Z.A.Ahmad, Ceram. Int. 40 (2014) 4777.

[5] T. Senguttuvan, H. Kalsi, S. Sharda, B. Das, Mater. Chem. Phys. 67, 1-3 (2001) 146.

[6] H. Alves, G. Tari, A. Fonsecca, J.M. Ferreira, Mater. Res. Bull. 33, 10 (1998) 1439.

[7] J. Park, H. Kim, Y. Jeong, Sep. Purif. Technol. 55 (2007) 321.

[8] M. Fukushima, M. Nakata, Y. Yoshizawa, J. Ceram. Soc. Japan 116, 1360 (2008) 1322.

[9] A.R. Jamaludin, S.R. Kasim, A.K. Ismail, M.Z. Abdullah, Z.A. Ahmad, J. Eur. Ceram. Soc. 35, 6 (2015) 1905.

[10] W. Wan, Y. Feng, J. Yang, S. Xu, T. Qiu, J. Eur. Ceram. Soc. 35 (2015) 2163.

[11] W. Wan, C. Huang, J. Yang, T. Qiu, Int. J. Appl. Glass Sci. 5 (2014) 401.

[12] R. Taktak, S. Baklouti, J. Bouaziz, Mater. Charact. 62, 9 (2011) 912.

[13] F.S. Ortega, F.A.O. Valenzuela, C.H. Scuracchio, V.C. Pandolfelli, J. Eur. Ceram. Soc. 23 (2003) 75.

[14] W. Wan, C. Huang, J. Yang, T. Qiu, Int. J. Appl. Glass Sci. 5 (2014) 401.

[15] A. Alleoni, Sci. Agric. 63 (2006) 291.

[16] T.C. Tan, K. Kanyarat, M.E. Azhar, Int. Food Res. J. 19 (2012) 303.

[17] N. Matsudomi, K. Nakano, A. Soma, A. Oichi, J. Agric. Food Chem. 50 (2002) 4113.

[18] J. Banjuraizah, H. Mohamad, Z.A. Ahmad, J. Alloys Compd. 509 (2011) 1874.

[19] K.L. Ngai, S. Capaccioli, J. Am. Ceram. Soc. 91 (2008) 709.

[20] N. Ibrahim, Z.A. Ahmad, H. Mohamad, Adv. Mater. Res. 501 (2012) 91.

[21] J.M. Tulliani, M. Lombardi, P. Palmero, M. Fornabaio, L.J. Gibson, J. Eur. Ceram. Soc. 33, 9 (2013) 1567.

[22] J.J. Liu, B. Zuberi, J.G. Weinstein, R.A. Dahl, W. Carty, "Cordierite fibre substrate and method for forming the same", US Patent 7,858,554 B2 (2010).

[23] X. He, B. Su, X. Zhou, J. Yang, B. Zhao, X. Wang, Ceram.-Silik. (2011) 3.

(Rec. 26/04/2017, Rev.08/08/2017, Ac. 21/10/2017) 